\title{
Omsorgstvang - av hensyn til hvem?
}

Bruk av tvang i behandlings- og omsorgsarbeid er alltid problematisk - faglig, etisk og rettslig. Fordi tvangsmessig intervensjon kan fremstå som nødvendig for å ivareta pasienters liv, helse og livskvalitet, er det likevel i ulike helselover åpnet for bruk av tvang på nærmere vilkår. I juridisk teori kalles dette omsorgstvang (1). Slik tvang kan anvendes av hensyn til den enkelte pasient og av hensyn til pårørende, ansatte eller medpasienter. I dette nummer av Tidsskriftet behandles tvang i sykehjem etter bestemmelsene i pasient- og brukerrettighetsloven kapittel 4A, som bare kan anvendes av hensyn til pasienten selv (2).

Inntil for 30-40 år siden kunne helsepersonell, dersom behovet fremsto som sterkt nok, selv beslutte om og iverksette bruk av tvang. Pasienters rett til medvirkning og selvbestemmelse har imidlertid ført til at tidligere hjemmelsgrunnlag, som helsepersonells plikt til å gi forsvarlig helsehjelp, ikke lenger gir anledning til bruk av tvang utover i nødssituasjoner (1).

Tvang kan derfor i dag utelukkende anvendes dersom man har hjemmel i lovverket. Bare de siste par tiårene er det gitt flere regelsett som har supplert tvangshjemlene i loven om psykisk helsevern og i smittevernloven. Dette gjelder helse- og omsorgstjenesteloven kapittel 9 (personer med utviklingshemning) og kapittel 10 (rusmiddelavhengige) (3). Også barnevernloven har flere bestemmelser som åpner for at undersøkelser og behandlingsinngrep kan skje ut fra barnets behov for helsehjelp og mot foreldrenes vilje (4). Det nyeste regelsettet ble innført som et nytt kapittel 4A i pasientog brukerrettighetsloven i 2006, mens reglene trådte i kraft først 1. januar 2009 for å gi tilstrekkelig tid til opplæring av helsepersonell.

Det er viktig å vurdere om slike tvangsregler anvendes på foreskreven måte og om de «passer» for de forholdene er de er ment å regulere og ikke innbyr til misbruk. Statens helsetilsyn har, på grunn av lovgitte rapporteringsplikter, oversikt over hvor mange tvangsvedtak som fattes årlig etter kapittel 4A. For de tre siste årene viser antallet vedtak en klart stigende tendens, fra 2075 (i 2010) via 2367 (i 2011) til 2715 (i 2012), men dette er tolket som at flere følger regelverket og fatter vedtak, ikke som at flere tvangsinngrep de facto gjennomføres (5). Fylkesmannen gjennomgår alle vedtakene og opphever etter en selvstendig vurdering vel $10 \%$ av dem. Dersom det ikke er klaget på et vedtak om helsehjelp etter kapittel 4A og helsehjelpen varer i mer enn tre måneder, skal Fylkesmannen på eget initiativ vurdere om det fortsatt er behov for tiltaket.

For å vurdere om regelverket er egnet og ikke innbyr til feiltolkninger, trenger vi imidlertid undersøkelser med et mer kvalitativt preg enn Fylkesmannens etterkontroll kan gi. Slike empiriske undersøkelser er ikke så enkle å gjennomføre. Det er derfor prisverdig at det nå er publisert en undersøkelse om helsepersonells erfaringer med bruk av tvang etter pasient- og brukerrettighetsloven kapittel 4A (2). Forfatterne hevder riktignok at samtykkekompetanse ikke er definert i loven, og dette gjøres til et gjennomgående problem. Men samme lovs § 4-3 andre ledd oppstiller et klart vilkår for bortfall av samtykkekompetanse, ved at «pasienten på grunn av fysiske eller psykiske forstyrrelser, senil demens eller psykisk utviklingshemming åpenbart ikke er i stand til å forstå hva samtykket omfatter».

Studien er utført ved bruk av fokusgruppeintervjuer med etterfølgende analyse av tre spørsmål. I hvilke situasjoner anvendes tvang? Hva er legenes rolle ved bruk av tvang? Hvilke utfordringer og erfaringer har personellet ved anvendelse av reglene i pasient- og brukerrettighetsloven kapittel 4A? Det er en pedagogisk oppstilling av funnene og en klar diskusjon av de utfordringer forfatterne har funnet at det nye regelverket fører til i praksis, blant annet at tvang også utøves av hensyn til andre enn pasienten selv. Det kan stilles spørsmål ved studiens representativitet og dermed muligheten for å trekke generelle slutninger, men det skal jeg la ligge.

Studien ble foretatt bare 5-11 måneder etter at reglene trådte i kraft. Av egen erfaring, som leder av en rådgivende gruppe som skulle følge anvendelsen av tilsvarende regler i (daværende) sosialtjenesteloven kapittel 6A vedrørende omsorgstvang overfor personer med utviklingshemning og utfordrende atferd, vet jeg at det tar tid før regler av denne typen blir anvendt etter hensikten. Dette til tross for ganske store informasjonskampanjer om regelverket i tiden før ikrafttredelsen. Vår gruppe var tildelt store ressurser fordi regelverket var sterkt omtvistet, og vi kunne vurdere tjenestetilbudet gjennom hjemmebesøk og intervjuer med pårørende/hjelpeverge og aktuelle tjenesteytere. Det er vanskelig å iverksette tilsvarende undersøkelser uten sikker offentlig finansiering og fast ansatte knyttet til gjennomføringen. Forfatterne må derfor berømmes for at de etter rimelig ressursbruk har vunnet nyttig kunnskap om kjennskapen til - og praktiseringen av - det aktuelle regelverket.

Ett viktig problem ved undersøkelser av tvang overfor personer uten forståelse av behovet for helsehjelp er å overskue hva klientens motstand mot et aktuelt tiltak er begrunnet $i$, og hvilken vekt som skal legges på denne. Felles for tvangsregler er videre at dersom pasienten avfinner seg med et tiltak, vil dette stort sett ikke være tvangsbruk etter regelverket. Om det ikke ytes motstand, kan helsepersonell etter pasient- og brukerrettighetsloven § 4-6 selv ta avgjørelser for personer uten samtykkekompetanse.

Behovet for tvangshjemler synes ikke å ta slutt. I flere runder er det $\mathrm{i}$ løpet av det siste halvannet år gitt nye regler i loven om psykisk helsevern. I tillegg har Stortinget nettopp vedtatt tilleggsregler i kapittel 4A (6). Varslings- og lokaliseringsteknologi i omsorgen for demente skal innføres, også mot eventuell motstand. Bruk av slike hjelpemidler kan utvilsomt virke «frigjørende» og gi en sikkerhet for hvor beboeren befinner seg. Men teknikk kan også erstatte omsorg og gi større distanse i det mellommenneskelige møtet. Også disse nye reglene bør følges opp med tilsvarende studier for å vurdere erfaringer og utfordringer for «eksemplarisk bruk» av moderne teknologi - og for å finne ut om utstyret tas i bruk mer av hensyn til personellet enn den enkelte beboer.

Aslak Syse
aslak.syse@jus.uio.no

Aslak Syse (f. 1946) er professor dr.juris., lege og instituttleder ved Institutt for offentlig rett, Universitetet i Oslo.

Forfatter har fylt ut ICMJE-skjemaet og oppgir ingen interessekonflikter

Litteratur

1. Kjønstad A, Syse A. Velferdsrett I. Grunnleggende rettigheter, rettssikkerhet og tvang. 5. utg. Kap. 10. Oslo: Gyldendal Akademisk, 2012.

2. Pedersen R, Hem MH, Gjerberg E et al. Bruk av tvang i sykehjem etter ny lovgivning. Tidsskr Nor Legeforen 2013; 133: 1935-9.

3. LOV 2011-06-24 nr. 30. Lov om kommunale helse- og omsorgstjenester m.m. (helse-og omsorgstjenesteloven).

4. LOV 1992-07-17 nr. 100. Lov om barneverntjenester (barnevernloven). §§ 4-10, 4-11, 4-12.

5. Tilsynsmelding 2012. Oslo: Statens helsetilsyn, 2013

6. Prop. 90 L (2012-2013). Endringer i pasient- og brukerrettighetsloven mv. 